\title{
The Diversity Of Macrozoobenthos River Aek Buru District Labuhan Batu Utara
}

\author{
Arman Harahap \\ Universitas Labuhan Batu, Sumatera Utara, Indonesia \\ *Email: armanhrp82@yahoo.co.id
}

\begin{abstract}
.
Benthos are organisms that live in the bottom of the waters, either animal or plant, living on the surface and in the bottom of the waters. This study aims to determine the diversity of Macrozoobenthos in the River Aek Hurry. The study began in November 2021 to January 2021. Sampling of macrozoobenthos done using a Surber net. based on differences in the substrate at the base of the river. Macrozoobenthos found in the Aek Buru consists of two Phyla, namely the Arthropods and Mollusks. Phylum Arthropoda are found is of the class of Insects belonging to the genus Hydropsyche, Polycentropus, psephenus, Dryops, Anthopotamu, Acroneuria and Triops. The phylum of Mollusks that are found are from a class of Bilvavia included in the Genus Corbicula and of the class of Gastropods of the Genera Melanoides and Melanatria. The abundance of macrozoobenthos of the highest on each of the stations is Polycentropus $(66,67$ ind/L) and Potadoma $(266,67$ ind $/ L)$. The abundance of macrozoobenthos of the highest found is Melanatria by 622,2 ind/L. Based on the value of the Index of Diversity $(H)(0,367-0,602)$ the index of dominance $(C)(0,132-0,386)$ and the evenness (E) $(0,367$ - 0,602) River Aek Buru in the category good condition with high species diversity. Physical and chemical factors of the water body capable of supporting life macrozoobenthos.
\end{abstract}

Keywords : Diversity, Macrozoobenthos, River Aek Buru.

\section{INTRODUCTION}

Benthos are organisms that live in the bottom of the waters, either in the form of animals and plants. The characteristics of the bentos are animals that have always lived on the base surface of the substrate such as mud, sand, and rocks (Lind,1979). Types of bentos that are often found at the bottom of the waters that is of class Polycheta, Mollusca and Insects (Odum,1994). Animals macrozoobenthos has a very important role as a key in the food network that serves as predators, suspension feeder, detritivor and Parasites (Teak, 2003). Makrozoobenthos also be used as a bioindicator of the waters, because it has properties that are very sensitive to changes in the aquatic environment they occupy (Wihm,1975). The existence of macrozoobenthos can be seen from the base substrate waters is very determine the development of the organism (Hynes, 1976). Fast-flowing river base substrate in the form of rocks is often found from the phylum Arthropoda and Mollusca. The substrate in the form of sand and silt is often found of the phylum Annelids and Mollusca.

The diversity of macrozoobenthos can describe the quality of the waters. If only animals macrozoobenthos certain found, it can be claimed that the waters are polluted, for example, Tubifex sp. The diversity of animals macrozoobenthos is not enough to determine the quality of the waters, but must be supported by factors of chemical physics, which also gives the effect of a waters(Sinambela, 1994). River Aek Buru located in the Village of Aek Buru in the Village of a Single Rock, sub-District NA IX-X, Kabupaten Labuhan Batu Utara, North Sumatra Province. River Aek Hurry have the rate of flow of the river is different based on the substrate on the bottom of the waters, so as to produce the type of macrozoobenthos are very diverse.

Research related to the diversity of macrozoobenthos is made by Prima (2012) found 4 genera of macrozoobenthos in the Flow of the River Tebas Kalimantan Barat. The results of the research Efrizal (2008), found 5 genera makrozobentos in the Waters of the River Sail Pekanbaru. The results of the research Erni (2014) found 8 genera of macrozoobenthos in the River Belumai Kabupaten Deli Serdang Province North 
Sumatera. The results of the research Manalu et all (2020), Find the 8 Genera makrozobentos in the Waters of the River Pandayangan.

Data regarding the diversity of macrozoobenthos in the flow of the River Aek Hurry up to now there is no, given the role and the benefits of macrozoobenthos in the River Aek Hurry, for it is research related to the diversity of macrozoobenthos in the Flow of the River Aek Hurry is important.

\section{MATERIALS AND METHODS}

Quarter and Temperate

The research, conducted by selama 3 moon, commenced from the moon November 2021 until January 2022. The research was conducted in The Sungai Aek Buru flow, A Single Coal Village, Naek-X District, North Coal Labourer County (File 1). Identification and analyzed data conducted at The Zoology Laboratory Of The Faculty of Science And The University's Education Sciences Lab In London.

\section{Tools and Materials}

A tool used in sampling of macrozoobenthos is a DO Meter, Surber Net, plastic bag, tape measure, paper label, fine brush, sample bottles, bottle winkler, stopwatch, puck secidian, magnifier, microscope, GPS (Geographic Position System). The materials used in the study were formalin 4\%, alcohol $70 \%$, MnSO4, KOH-KL, a solution of $\mathrm{H} 2 \mathrm{SO} 4$ concentrated.

\section{RESEARCH METHODS}

General Description Of The Study Site

SungaiAek Buru in the Village of a Single Rock, sub-District Na IX-X Kabupaten Labuhan Batu Utara. River Aek Hurry have the condition of the waters of the fast-flowing medium and a lot of the rapids both large and small with the base substrate in the form of rocks gravel and large and sandy.

Sampling of macrozoobenthos is done based on the difference in the hue of the environment on the substrate every satsiun, by using the method of Cluster Random Sampling which is divided into 3 stations.

Sampling using Surber Net is only used on the waters with the condition of the substrate is rocky with how to put on the base of the height of the river is not too deep, with the direction of the openings of the net Surber Net facing the opposite direction with the current of the river flowing. Net Surber lifted and the results of such a sample is inserted into the plastic container shelter labeled, with the given preservation in formalin $4 \%$. The results of the sample obtained will be done sorting to facilitate the identification of such samples. To perform the sorting of the sample is carried out in the laboratory of Zoology. Sample of already sorted then in the photo and is inserted into the bottle of the film, and performed the identification of the sample (Michael, 1984).

The measurement of the environmental factors measured is the temperature of the water using a mercury thermometer, the water depth was measured using a stick-scale, the speed of the current is measured using a stopwatch measure time with the help of bola pimpong, measure kecerah water use pieces sechi, the measurement of the $\mathrm{pH}$ of the water using $\mathrm{pH}$ paper and for the measurement of the levels of kandngan dissolved oxygen and $\mathrm{CO} 2$ smoke in the waters will be done directly in the field by using a modified titration Winkler.

\section{RESULTS AND DISCUSSION}

Macrozoobenthos found on a third research station in the flow of the River Aek Buru comes from the Phylum of Arthropods and Mollusks. Phylum Arthropoda are found derived from the Class of Insects. The phylum of Mollusks found comes from the class of Gastropoda and Bilvavia. Macrozoobenthos found from the Phylum Arthropod is of the Order Trichoptera as much as 2 genera, while Molluses is derived from the Order 
Sorbeoconcha as much as 3 genera (Table 1). Based on the results of the research found on the third station, the abundance of the genus macrozoobenthos highest at station I is Polycentropus by $66,67 \mathrm{ind} / \mathrm{m} 2$, at station II Genus Melanantria have the value of an abundance of the highest of $622,67 \mathrm{ind} / \mathrm{m} 2$, whereas at Station III there are two genera that have the value of an abundance of the highest Corbicula and Potadoma with the value of an abundance of 266,67 ind/m2 (Table 2). Communities of macrozoobenthos in the River Aek Buru has a level of diversity that varies based on the difference in the base substrate of the river. The diversity of macrozoobenthos with the base substrate rocky at the station I to be the highest with a value of 2,085 diversity and the lowest occurred in station III $(1,002)$ with the substrate muddy bottom (Table 3$)$.

Environmental parameters measured include temperature, $\mathrm{pH}$ and flow velocity. The Data characteristics of the habitat makroozoobentos in the three stations of the River Aek Buru Landak Regency look of the water temperature ranges from 27 to 28 oC with a flow speed of $0.8-0.19 \mathrm{~m} / \mathrm{s}$ and the $\mathrm{pH}$ range $6-7$ (Table 4).

Table 1. Macrozoobenthos found on a third research station

\begin{tabular}{|c|c|c|c|c|}
\hline Filum & Class & Ordo & Famili & Genera \\
\hline Athropoda & \multirow[t]{7}{*}{ Insekta } & \multirow[t]{7}{*}{ Trichoptera } & Hydropsychidae & Hydropsyche \\
\hline Polycentropodidae & & & & Polycentropus \\
\hline Coleoptera & & & Psephenidae & Psephenus \\
\hline Odonata & & & Driopidae & Dryops \\
\hline Ephemeroptera & & & Potamanthidae & Anthopotamus \\
\hline Plecoptera & & & Perlidae & Acroneuria \\
\hline Notostraca & & & Triopsidae & Triops \\
\hline Moluska & \multirow[t]{3}{*}{ Gastropoda } & Sorbeoconcha & Thiaridae & Melanoides \\
\hline & & Potadoma Melanantria & & \\
\hline Bilvavia & & Verenoida & Corbiculidae & Corbicula \\
\hline
\end{tabular}

Table 2. Abundance (K) ind $/ \mathrm{m} 2$, the Relative Abundance (KR), and the Relative Frequency (FR) \% at each Research Station Macrozoobenthos in the Flow of the River Aek Buru.

\begin{tabular}{cccccccccc}
\hline \multirow{2}{*}{ Genus } & \multicolumn{3}{c}{ Stasiun I } & \multicolumn{3}{c}{ Stasiun II } & \multicolumn{3}{c}{ Stasiun III } \\
\cline { 2 - 9 } & $\mathrm{K}$ & $\mathrm{KR}$ & $\mathrm{K}$ & $\mathrm{KR}$ & $\mathrm{FR}$ & $\mathrm{K}$ & $\mathrm{KR}$ & FR \\
\hline Hydropsyche & 33,3 & 9,37 & 7,7 & - & - & - & - & - & - \\
Polycentropus & $* * 66,67$ & 18,76 & 7,7 & - & - & - & - & - & - \\
Psephenus & 22,2 & 6,24 & 7,7 & - & - & - & - & - & \\
Dryops & 22,2 & 6,24 & 7,7 & - & - & - & - & - & - \\
Anthopotamus & 55,56 & 15,64 & 7,7 & - & - & - & - & - & - \\
Triops & $* 10,3$ & 3,12 & 7,7 & - & - & - & - & - & - \\
Melanoides & 55,56 & 15,64 & 23,1 & 266,67 & 20,69 & 33,3 & $* 88,89$ & 14,286 & 37,5 \\
Melanantria & - & - & - & $* * 622,2$ & 48,276 & 11,1 & - & - & - \\
Potadoma & 44,4 & 12,49 & 23,1 & 266,67 & 20,69 & 33,3 & $* * 266,67$ & 42,857 & 37,5 \\
Corbicula & - & - & - & $* 133,3$ & 10,345 & 22,2 & $* * 266,67$ & 42,857 & 25,0
\end{tabular}


Table 3. The level of Diversity, Evenness and Dominance of Macrozoobenthos in the Flow of the River Buru

\begin{tabular}{lccc}
\hline \multicolumn{1}{c}{ Parameters Measured } & Station & III \\
\hline Water temperature (oC) & I & II & 28 \\
Depth $(\mathrm{cm})$ & $27-28$ & 135 & 186 \\
Current speed (m/s) & 38 & 0,12 & 0,21 \\
Ph & 0,9 & $20-45$ & $50-57$ \\
\hline Transparency $(\mathrm{cm})$ & $7-16$ & 7 & 6
\end{tabular}

Table 4. The Results Of Measurements Of Parameters Of Chemical Physics Waters Of The River Aek Buru At Each Research Station

\begin{tabular}{cccc}
\multirow{2}{*}{ Indeks } & \multicolumn{3}{c}{ Station } \\
\cline { 2 - 4 } & I & II & III \\
\hline Indeks Shanon Winner (H') & 2,085 & 1,237 & 1,002 \\
Indeks Kemerataan (E) & 0,602 & 0,367 & 0,380 \\
Indeks Dominansi Simpson (C) & 0,132 & 0,329 & 0,386 \\
\hline
\end{tabular}

\section{Discussion}

Macrozoobenthos found on the flow of the River Aek Buru as many as 10 genera, which are divided into two phyla, namely the Arthropods and Mollusks, and is made up of Family Hydropsychidae, Polycentropodidae, Psephenidae, Driopidae, Potamanthidae, Perlidae and Triopsidae. Family that are included in the Phylum of Mollusks is Corbiculidae.

Phylum Arthropoda is the phylum that are found in the River Aek Hurry. The phylum is still largely in the form of the phase of the larvae. A lot of the discovery of the larvae of these because the waters of the River Aek Buru is very supportive for the growth of the larvae of insects. High levels of oxygen $(5-6 \mathrm{ppm})$ with the level of brightness in the waters $(7-57 \mathrm{~cm})$ be a supporting factor for the growth of the larvae of insects, with the condition of the substrate the basic form of the rocks and the speed of the strong currents $(0.8 \mathrm{~m} / \mathrm{s})$ (Table 4). Cairns and Dickson (1981), explained that the macrozoobenthos in the phase of the larvae of the insects commonly found in crystal clear water with oxygen levels are quite high.

Polycentropus is a genus of the Phylum Arthropoda are found in many places. This Genus is entered into the order Trichoptera. Polycentropus have a morphology with a dorsal plate on the part of the caput, on each segment of the body has a texture that is very soft and has a body shape that is flattened (Pennak, 1978).

Station I is the station with the substrate bottom waters in the form of stone-rocks with current speed of $0.8 \mathrm{~m} / \mathrm{s}$ (Table 4), the abundance of the highest at station I is Polycentropus with the value of 
an abundance of $66.67 \mathrm{ind} / \mathrm{m} 2$ (Table 2). The high abundance of Polycentropus because substrate in the form of rocks is a substrate which is better for survival of strong currents. The morphology of the body that supports the existence of a pair of legs hook that serves as a tool to attach themselves to substrate (Pennak, 1978). Other factors can be seen from the level of the $\mathrm{pH}$ of the waters reach the 7 is the $\mathrm{pH}$ value of the good for the life of Polycentropus. According to Cairns and Dickson (1971), the type of the may-flies (Ephemeroptera), stone-files (Plecoptera) and Caddies-files (Tricopthera) found in crystal clear water with a $\mathrm{pH}$ value range of 6-8.

Abundance is lowest at station I is Triops with the value of an abundance of $10.3 \mathrm{ind} / \mathrm{m} 2$ (Table 2). The low abundance of the Genus Triops caused by the condition of the waters of the rate $(0.9 \mathrm{~m} / \mathrm{s})$ is less support for the life of the Triops. Morphology owned Triops very small and soft, causing the genus is not able to adapt to the well, thus causing more easily carried away by the current. Triops are found in the rivers that does not have the speed of the rushing currents and the abundance of this genus will look high depends on several factors such as the quality of the food (Cummins, 1975). Subtrat berpasir merupakan aliran Sungai Aek Buru pada stasiun II dengan kecepatan arus 0,12 m/s (Tabel 4). Kelimpahan tertinggi di stasiun II yaitu Genus Melanatria dengan nilai kelimpahan $622,2 \mathrm{ind} / \mathrm{m}^{2}$ (Tabel 2). Tingginya kelimphan Melanantria dikarenakan subtrat berpasir merupakan subtrat yang cocok untuk pertumbuhan Genus Melanantria dengan didukung morfologi dari Melanantria yang besar diantara Gastropoda lainnya menyebabkan Melanantria lebih mudah bergerak untuk beradaptasi. Menurut Suwignyo (1998), Melanantria lebih banyak ditemukan pada perairan yang bersubtrat lumpur dan berpasir karena digunakan sebagai tempat mendapatkan makanan dan bertahan hidup.

The abundance of the lowest in station II, namely in the Genus Corbicula with the value of an abundance of $133,3 \mathrm{ind} / \mathrm{m} 2$ (Table 2). Conditions of the substrate sand is not very supportive for the growth of Corbicula, because Corbicula including animal eaters suspension that his life was on the base substrate of the software does not sandy. Bivalves are classified into groups of animal eaters suspension, digger and eater of the deposit, because that's the amount tends to be abundant on muddy sediment and software. Also explain that Bilvavia is an animal whose life is settled at the bottom of the waters with how to immerse yourself in the sediment software.

Station III has a substrate base in the form of mud. Macrozoobenthos found amounted to two genera which have the value of the abundance of the same height, with the value of 266,67 ind/m2 (Table 2), namely in the Genus Potadoma and Corbicula. The condition of the waters at station III has a $\mathrm{pH}$ value of 6 with a current speed of $0.21 \mathrm{~m} / \mathrm{s}$ (Table 4). The high value of the abundance of both genera is supported by the substrate, namely in the form of muddy sediment. The morphology of the two genera it has a shape that is small compared to the macrozoobenthos in the genus Melanantria. The shape of his body is small cause Potadoma and Corbicula is actively moving to survive. The $\mathrm{pH}$ value of 6 will also be one of the factors that support the growth of this genus. Hynes (1976), explains that the Gastropods are more common on the waters of the bersubtrat the mud to obtain food and to the formation of the eggshell.

The abundance of the lowest in station III are in the Genus Melanoides with an abundance 88,89 ind $/ \mathrm{m} 2$. The low abundance of Melanoides due to the state of the substrate that does not support the muddy. Melanoides is found in many areas bersubstrat rocks with the content of the dissolved oxygen is high. Erni (2014), explained that the Genus Melanoides live in waters with high oxygen content and 
able to survive in waters containing low organic matter.

The results showed that the value of The Keanekaragamanan third research station in Sungai Aek Hurry range from 1,004-2,089 (Table 3). These values show the diversity at station I is still relatively good because the value of $(\mathrm{H})$ close to 3 , on the contrary, if the value of $\mathrm{H}$ close to 0 then the diversity is relatively low and the condition of the waters is less good. The high level of diversity at station I is due to the oxygen level of good (6 ppm) (Table 3 ) and the state of the substrate bottom waters are able to support the life of the macrozoobenthos of the.

The dominance of macrozoobenthos the highest of 0,386 (Table 3), namely at station III with the substrate muddy bottom. The Genus that dominates is the Genus Potadoma and Corbicula has the value of an abundance of very dominate among the genus of which there are. The condition of environmental factors on the third station, the waters of the River Aek Buru is still support for the life of the macrozoobenthos in the waters. The temperature of the water on the third station ranged between 27-28oC (Table 4). In general, the range of temperature is quite good for the life of the macrozoobenthos.

$\mathrm{PH}$ value on on the third station was also influential for the growth of the macrozoobenthos in the waters, the results of $\mathrm{pH}$ measurement at each station observations ranges between 6-7 (Table 4), this condition shows that the area of the River Aek Buru is still support for the life of the macrozoobenthos, because the optimal $\mathrm{pH}$ in the waters ranges from 6-8 (Soegianto, 2005).

Dissolved oxygen and $\mathrm{CO} 2$ in the waters is a factor that is very supportive for the life of the macrozoobenthos. The results of observations on the third station, the value of the dissolved oxygen ranged between 5-6 ppm and $\mathrm{CO} 2$ values at all three stations tend to be $5 \mathrm{ppm}$ (Table 4). Oxygen in the waters of the still very supportive for the life of the macrozoobenthos because the minimum levels of dissolved $\mathrm{O} 2$ for aquatic organisms is 4 ppm (Suwondo, 2005).

\section{CONCLUSION}

Macrozoobenthos found on the flow of the River Aek Rush as many as 10 genera, which are divided into two phyla, namely the Arthropods and Mollusks, and is made up of Family Hydropsychidae, Polycentropodidae, Psephenidae, Driopidae, Potamanthidae, Perlidae and Triopsidae. Family that are included in the Phylum of Mollusks is Corbiculidae.

Phylum Arthropoda is the phylum that are found in the River Aek Buru. The phylum is still largely in the form of the phase of the larvae. A lot of the discovery of the larvae of these because the waters of the River Rombok Banangar very supportive for the growth of the larvae of insects.

\section{REFERENCES}

[1] Lind, OT, 1979, Hand Book of Common Methods in Limnology, Sec Ed, Mosby Company, St. Louis, Toronto, London.

[2] Odum, EP, 1994. Dasar-Dasar Ekologi. Edisi Ketiga. Universitas Gadjah Mada Press. Yogyakarta.

[3] Wilhm, JF, 1975. Biological Indicators Pollution Dalam Whitton, BA, River Ecology, Blackwell Scient Publ, Oxford.

[4] Hynes, HBN., 1976. The Ekologi With Of Running Water. Liverpool University Press. England.

[5] Prima, SY, 2012, Kualitas Perairan Sungai Tebas Kecil di Tinjau Dari Struktur Komunitas Makrozoobentos, Fakultas Matematika dan Ilmu Pengetahuan Alam Universitas Tanjung Pura, Pontianak, Skripsi. 
[6] Erni, DF, 2014, Kondisi Perairan dan Struktur Komunitas Makrozoobentos di Sungai Belumai Kabupaten Deli Serdang Provinsi Sumatra Utara. Fakultas Perikanan dan Ilmu Kelautan, Isntitut Pertanian Bogor. Volume 4, No. 1, February 2021, Page: 1236-1241

[7] Manalu, B. N \& A, Harahap. 2020, The Study of Quality of the River Pandayangan in His Review of the Factors of Physical-Chemical. Budapest International Research and Critics Institute-Journal (BIRCIJournal).

[8] Cairns, JR \& KL, Dickson, 1971, Journal of the Water Control Federation, Vol.42.

[9] Cairns, JR \& KI, Dickson, 1981, Biological Methods for Assesment of Water Quality, Merican Society Testing and Material (ASTM). America.

[10] Cummins, KW, 1975, River Ecology, Editor Whitton, BA, Black Well Scients Publ. Oxford.

[11] Efrizal, T, 2008, Struktur Komunitas Makrozoobentos Perairan Sungai Sail Kota Pekanbaru. Fakultas Perikanan dan Ilmu Kelautan, Universitas Riau, Pekanbaru. $<$ http://www. Journal of Enviromental Science.com/s

[12] Jati, WN, 2011. Struktur Komparasi Keanekaragaman Bentos di Waduk Sempor, Waduk Kedungombo dan Waduk Gajah Mungkur Jawa Tengah, Fakultas Biologi Universitas Atmajaya, Yogyakarta

[13] Michael, P., 1984. Metode Ekologi Untuk Penyelidikan Ladang dan Laboratorium, UI Press, Jakarta. Nybakken, JW, 1992, Biologi Laut, Suatu Pendekatan Ekologis, Gramedia, Jakarta.

[14] Pennak, RW, 1978, Freshwater Invertebrates of The United States, 2rd, ed. A, Willey Interscience Publ, Jhon Willey, New York.

[15] Soegianto, A, 2005. Ilmu Lingkungan. Cetakan Pertama, Surabaya, Penerbit Universitas Airlangga.

[16] Suwignyo, S, 1998, Avertebrata Air, Jilid I, Penerbit Penebar Swadaya.

[17] Suwondo, EF, 2005, Struktur Komunitas Gastropoda pada Hutan Mangrove di Pulau Sipora Kepulauan Mentawai Sumatra Barat, Universitas Riau, Pekanbaru. 